\title{
Evaluation of activated carbons produced from by-products sugar crops grown in Egypt: I. Chemical composition of starting materials
}

\author{
H.N. Hafez *, M.S. El-Gharabli *, M.H. Mohamed*, S.Y. Beshet** and A.H. Sasy ** \\ * FoodSci. Dept., Fac. of Agric. Moshtohor, Benha Unvi., Egypt. \\ ** Sugar Crops Research Institute, Agriculture Research Center, Egypt.
}

\begin{abstract}
In an attempt to produce some active carbons (AC's) in Egypt, various by-products of sugar crops (sugar cane bagasse (SCB), sugar cane trash (SCT), dry sugar beet pulp (SBP) and molasses) were examined chemically and technologically to test their suitability as starting raw materials for preparation of AC of good efficiency. Chemical analysis revealed that SBP had the highest ash and crude protein contents. SCT gave the highest ether extract, while, the Sugar cane bagasse SCB exhibited the highest content in total carbohydrates and crude fibers. Molasses exhibited the highest content in reducing and non-reducing sugars, while the other byproducts recorded lower values. Cellulose and lignin had a range of $32.75-34.57 \%$ and $1.93-16.35 \%$ on dry basis, respectively, in all sugar crops by-products. Dry SBP had the highest content in calcium. Beet molasses contained the highest content in potassium sodium, while the cane molasses contained the highest content in iron. The different starting materials were handled in the laboratory in different combinations and subjected to carbonization and activation and binder addition procedures to introduce eventually 24 treatments of produced experimental AC's using different chemical and physical activation steps during $\mathrm{AC}^{\prime}$ 's preparation.
\end{abstract}

Key words: Active carbons - Sugar cane bagasse - Sugar cane trash - Beet pulp - Molasses.

\section{Introduction}

The production of activated carbon (AC) from agricultural by-products has potential economic and environmental impacts. First, it converts unwanted, low -value agricultural waste to useful, high-value adsorbents. Second, AC's are increasingly used in water streams to remove organic chemicals and heavy metals, thus have environmental and /or economic impacts. Third, it will reduce the importation of AC wherefore increasing any country economic situation (Abia et $\boldsymbol{a l}$., 2003). It is well known that any activated carbons can be produced from virtually any type of carbonaceous materials such as agricultural wastes, shells, stones and sugar crops by-products (Zhang et al., 2007).

Sugar cane bagasse (SCB) is a by-product of sugarcane industries obtained after the extraction of juice in the process of sugar production. In its natural state is a poor adsorbent of organic compound such as sugar colorants and metal ion (Xia and Len, 1999) as well as Blanco et al. (2000) stated that bagasse was found suitable resource for preparation of AC. Qureshi et al. (2008) investigated bagasse to make AC to be used in sugar industries for the removal of colorants from sugar liquor and for treatment of drinking water and industrial waste water. Samipa and Chaudhuri (2012) studied bagasse as a suitable resource for AC production. Recently, Mutah et al. (2013) investigated the best production conditions for making AC from sugar cane bagasse using steam activation, with the purpose of elimination of cadmium ions from water streams.

Sugar beet pulp (SBP) is a by-product of extracting table sugar from sugar beet and it is an excellent source of digestible fibers while being relatively low in crude protein (approximately 810\%). Torres-Pérez et al. (2012) converted, at laboratory scale, (SBP) into activated carbons and they demonstrated that the production of $\mathrm{AC}$, at labscale, is feasible and leads to genuine activated carbons with different intrinsic properties.

Molasses, in general, is the syrupy material left after the removal of sugar from the mother syrup of sugar cane or sugar beet juices during sugar production process (Meade and Chem, 1977). Therefore, Legrouri et al. (2005) prepared AC from sugar cane molasses by chemical activation with $\mathrm{KOH}$ at various temperatures and concluded that sugarcane molasses can be an excellent starting material to preparation of high porous carbons.

Sugar cane dry trash (SCT), a residue in cane fields which is the dry brown leaves attached to the cane stalk, has been reported to have significant potential as a biomass fuel (Prabhakar et al., 2010). However, this potential fuel is wasted by burning it in open fields after harvesting producing harmful emissions of gases like $\mathrm{N}_{2} \mathrm{O}, \mathrm{CH}_{4}$ and $\mathrm{CO}_{2}$ in addition to $\mathrm{CO}$.

The objective of this work was to analyze chemically and also investigate the suitability of various by-products of sugar cane crops, which are abundant in many regions of Egypt, to produce 
various active carbons from different combinations of these starting sources. Moreover, to evaluate the absorption potency of produced experimental AC's for removing colored dyes and also the toxic cadmium ions from their aqueous solutions.

\section{Materials and Methods}

Starting materials for active carbon preparation:

1- Sugar cane trash (SCT) and sugarcane bagasse (SCB) were obtained after juice extraction using commercial 3-5 roll mills from local sugar cane juice pressing stores at Giza Governorate, Egypt.

2- Sugar cane molasses (SCM) was obtained from Sugar Cane Factory (Abokorkas, Elmenia Governorate, Egypt).

3- Sugar beet pulp (SBP) and sugar beet molasses (SBM) were obtained from Sugar Beet Factory (El-Hamoul Factory, Kafr El-Sheikh Governorate, Egypt).

\section{Materials for testing performance of experimental active carbon:}

1- Aqueous solutions of Methylene blue dye $\left(\mathrm{C}_{16} \mathrm{H}_{18} \mathrm{ClN}_{3} \mathrm{~S}\right)$, the sorbate, used in the present study, are a monovalent cationic dye. In dye classification it is classified as C. I. Basic blue 9 and C. I. 52015. It has a molecular weight of 373.9.

2- Aqueous solutions of cadmium ions ( Merck, Germany) in the form of $1 \mathrm{M}$ cadmium chloride $(\mathrm{Cd} \mathrm{Cl} 2 . \mathrm{H} 2 \mathrm{O}$ solution.

3- Phosphoric acid (Merck, Germany) was employed for treating the starting by products during processing of $\mathrm{AC}$.

\section{Process of active carbon production and activation:}

a) Raw material preparation into different treatments: Sugar cane bagasse (SCB) and sugar beet pulp (SBP) were milled and sieved to produce fine powder, which maintained in polyethylene bags until used as a source of lignocelluloses materials. The different precursors for experimental AC's were handled in the laboratory through mixing different combinations of them (with or without acid / binder addition) to prepare eventually 24 different treatments as follows:

1. SCT alone (without acid treatment).

2. SCT alone (with acid treatment).

3. SCB alone (without acid treatment).

4. SCB alone (with acid treatment).

5. SBP alone (without acid treatment).

6. SBP alone (with acid treatment).

7. SCT, SCB and SBP were mixed in equal proportions without acid treatment to a mixture (Mix group).

8. SCT, SCB and SBP were mixed in equal proportions with acid treatment.
9. SCT was mixed with equal volume of SBM without acid treatment.

10. SCT was mixed with equal volume of SBM with acid treatment.

11. SCT was mixed with equal volume of SCM without acid treatment.

12. SCT was mixed with equal volume of SCM with acid treatment.

13. SCB was mixed with equal volume of SCM without acid treatment.

14. SCB was mixed with equal volume of SCM with acid treatment.

15. SCB was mixed with equal volume of SBM without acid treatment.

16. SCB was mixed with equal volume of SBM with acid treatment.

17. SBP was mixed with equal volume of SCM without acid treatment.

18. SBP was mixed with equal volume of SCM with acid treatment.

19. SBP was mixed with equal volume from SBM without acid treatment.

20. SBP was mixed with equal volume from SBM with acid treatment.

21. SCB, SBP, SCT and SBM were mixed equally to make a mixture (Mix group) without acid treatment.

22. SCB, SBP, SCT and SBM were mixed equally to make a mixture with acid treatment.

23. SCB, SBP, SCT and SCM were mixed equally to make a mixture without acid treatment.

24. SCB, SBP, SCT and SCM were mixed equally to make a mixture with acid treatment.

b) Activation steps:

1) Chemical impregnation of raw materials: Two main chemical impregnation processes were applied to form two main groups of the 24 pretreated experimental treatments as follows :a) Impregnation with acid, and b) Impregnation without acid (with only distilled water).

In the first group (12 treatments), phosphoric acid $(50 \% \mathrm{v} / \mathrm{v})$ acid solution was used to impregnate them through soaking for $24 \mathrm{hr}$. To group No.1 of treatment combination, about $150 \mathrm{~cm}^{3}$ phosphoric acid of pre adjusted concentration was added. This amount of acid was found to be sufficient to cover the whole mass and to give a paste of soft consistency. However, to group No.2, the impregnation process was carried with distilled water.

(2) Carbonization: All the impregnated samples from the both groups of by-products combinations were left overnight at then admitted into a tubular electric furnace. AC carbonization was performed at $400^{\circ} \mathrm{C}$ for $4 \mathrm{hr}$.

(3) Washing step: The obtained granular carbonized mass was left to cool, and washed thoroughly with hot distilled water to about neutrality (using litmus paper ).The presence of phosphate was 
recognized in the acid treated samples by the white precipitate of $\mathrm{Pb}_{3}\left(\mathrm{PO}_{4}\right)_{2}$.

(4) Final step: $\mathrm{AC}^{\prime} \mathrm{s}$ were dried at $120^{\circ} \mathrm{C}$ in an air oven and stored in polyethylene bags for subsequent characterization and adsorption studies.

\section{Proximate chemical composition:}

Moisture, crude proteins, ether extract, crude fibers and ash contents were determined according to the method described by A.O.A.C. (2005).

\section{Chemical analysis of available and non-available carbohydrates:}

Total carbohydrates were determined according to the method described by Dubois et al. (1956). Reducing and non-reducing sugars contents were determined according to the method described by A.O.A.C. (2005). The determination of fiber fractions (cellulose, hemicelluloses and lignin) in dried sugar beet pulp, sugar cane bagasse and cane trash was accomplished according to Georging and Van Soest (1975) where samples were analyzed to acid detergent fiber fraction (ADF) neutral detergent fiber fraction (NDF) and acid detergent lignin (ADL). Cellulose (weigh loss of ADF upon extraction with $72 \% \mathrm{H}_{2} \mathrm{SO}_{4}$ ) and hemicelluloses were calculated as follows:

Hemicelluloses $=$ NDF - ADF. While, Cellulose $=$ ADF - ADL.

\section{Determination of minerals:}

a) Determination of silica in sugar crops byproducts: Silica were determined by the titration method used with samples of agricultural raw material wastes according to the method of AOAC( 1990) with some modifications as follows: The washed by-product materials were moistened with 3 $\mathrm{ml}$ of $\mathrm{H}_{2} \mathrm{SO}_{4}(2 \mathrm{~N})$, and then about $5 \mathrm{ml}$ of $48 \%$ high fiber is added slowly. The liquid is evaporated on a sand bath on the electric hot plate until the crucible contents were almost dry and $\mathrm{SO}_{3}$ begins to be evaluated. The crucible is cooled, 1 to $2 \mathrm{ml}$ more higher fiber is added and the crucible is rotated in an inclined position so as to dissolve any $\mathrm{SiO}_{2}$ that may be stuck to the sides. The acid was evaporated to complete dryness on the sand bath then the uncovered crucible, in an inclined position, was gradually heated with a flame. The heating is finished with a fairly strong flame of a maker bummer for a few minutes. The crucible and contents were weighed, and this weight was subtracted from the previous weight to get the loss in weight of pure $\mathrm{SiO}_{2}$.

b) Determination of minerals in sugar crops byproducts: Sodium, calcium, potassium and iron were determined all sugar crops byproducts using flame photometer method according to the method of AOAC ( 1990). c) Determination of minerals in aqueous solutions: Cadmium contents in the aqueous solution were determined using the flame system of the atomic absorption spectrophotometry (AAS) method described by Association of Official Analytical Chemists methods (AOAC, 1990).

\section{Statistical analysis:}

Statistical analysis was applied to some data. Data were treated as data for complete randomization design. Least significant difference (L.S.D.) was calculated at 0.05 level of significance. These analyses were according to Snedecor and Cochran (1980).

\section{Results and Discussion}

\section{Proximate Chemical composition of raw materials:}

Data in Table (1) revealed that moisture content averaged was $9.21 \%$ for the three sugar cane byproducts vs. $7.96 \%$ in the two sugar beet byproducts. The highest moisture content (10.09\%) was signaled in sugar cane molasses and also in sugar beet molasses $(10.06 \%)$, while dry sugar beet pulp had the lowest moisture content $(5.87 \%)$, over all other values for sugar crops by-products It is interesting to note that moisture content can be used for indirect calculation of fiber content in sugar cane (Anwar, 2010).

Crude protein content in dry SBP was found high and amounted to $10.70 \%$, while SCB, sugar cane molasses and SCT reached to 5.08, 3.04 and $5.79 \%$, respectively, on dry matter basis.

Dry SBP had the highest ash content $(9.09 \%)$ compared to other sugar by-products which contained 2.58, 6.35 and $3.30 \%$ with SCB, sugar cane molasses and SCT on dry basis, respectively. Moreover, SCT gave the highest ether extract $(1.17 \%)$, while dry SBP recorded the lowest value $(0.38 \%)$ on dry basis. Molasses from both sugar crops by-products were found free of ether extract.

Total carbohydrates were found the principal component is all the tested by- products. The highest total carbohydrates value was signaled by SCB $(91.95 \%)$ while the lowest value was recorded by dry SBP $(79.83 \%)$ on dry matter basis.

Comparing the obtained data for proximate chemical composition of sugar crops by-products with literature data revealed that comparable results were attained by Youssif (1996) who showed that dried SBP and SCB contained crude protein 9.86, $3.83 \%$, ash $4.88,2.02 \%$ and ether extract 1.42 , $3.53 \%$. In agreement to the found data, Andrei et al. (2012) reported that SBP content showed comparable range of values in protein (10.4-11.20\%) and ash (3.40-3.90\%). Moreover, in agreement to the found data, Beshai (2001) cleared that dried SCB products 
were poor in crude protein $(3.4 \%)$. In addition, Curtin (1983) demonstrated that, normally, molasses contains about $46 \%$ total sugars, $3.0 \%$ crude proteins and $0.0 \%$ fat.

\section{Available carbohydrate components:}

On dry matter basis, both SCM and SBM signaled highest reducing sugars (43.50 and 42.24\%, respectively). Lower values were found in SCT $(2.64 \%)$ and SCB $(1.40 \%)$, while dry SBP recorded the lowest value $(1.40 \%)$. Similarly, non-reducing sugars in sugar beet molasses and sugar cane molasses (27.31 and $25.51 \%$, respectively) were of higher values compared to dry beet pulp $(3.71 \%)$ and SCB (3.48\%). SCT had the lowest content $(1.69 \%)$.Total sugars also showed the same trend that molasses from both sugar crops exhibited higher content(70.99-71.39\%) than the other by-products which exhibited comparable low content (4.41$5.31 \%)$.On the other hand the determined total carbohydrates data showed that they comprised the first major content with all by-products tested (79.83-91.8\%) (Tables 2 \& 3).

In agreement to the obtained data, Kühnel et al. (2011) reported that dry SBP consisted of $68 \%$ up to $75 \%$ of carbohydrates (dry matter). However, sugar cane and sugar beet molasses content was reported to be not less than $48 \%$ of total sugars as stated by A.A.F.C.O. (2008).

The found values for SBP compared well with those of Allam (1993) who indicated values of $3.71 \%$ for non reducing sugar and $0.63 \%$ for reducing sugar. However, Youssif (1996) reported different values for dried SBP and SCB (reducing sugars 3.95, 1.05\% and non reducing sugar 12.36, $4.64 \%$, respectively). Furthermore, values for reducing and non-reducing sugars in molasses found the present study were lower than those signaled by Abdel-Aziz et al. (2012) who reported a value for reducing sugars of $22.00 \%$, but non-reducing sugars (sucrose) value was $25.50 \%$.

In contrast to the found data for molasses, lower total sugars (46\%) were reported by Curtin (1983). Similarly, Dumbrepatil et al. (2008) reported that molasses contained sucrose $(31 \%)$, glucose $(9.5 \%)$, fructose $(10 \%)$ and nitrogen $(0.95 \%)$. Moreover, Mariam et al. (2009) found that molasses contained only $45-60 \%$ total sugars.

It is interesting to note that Sangkharak et al. (2011) found that the high reducing sugars concentration at $4.5 \mathrm{~g} / \mathrm{L}$ was obtained from SCT at an amount of $30 \mathrm{~g}$ leaf waste/L.

Table 1. Proximate chemical composition of sugar cane and sugar beet by-products used as starting materials for experimental active carbon production.*

\begin{tabular}{|c|c|c|c|c|c|c|c|c|c|}
\hline \multirow{2}{*}{$\begin{array}{l}\text { Starting } \\
\text { by-products }\end{array}$} & \multirow[b]{2}{*}{$\begin{array}{c}\text { Moisture } \\
\%\end{array}$} & \multicolumn{2}{|c|}{$\begin{array}{c}\text { Ash } \\
\%\end{array}$} & \multicolumn{2}{|c|}{$\begin{array}{c}\text { Crude proteins } \\
\%\end{array}$} & \multicolumn{2}{|c|}{$\begin{array}{c}\text { Ether extract } \\
(\%)\end{array}$} & \multicolumn{2}{|c|}{$\begin{array}{c}\text { Total carbohydrates } \\
(\%) * *\end{array}$} \\
\hline & & $\begin{array}{c}\text { On } \\
\text { wet } \\
\text { basis }\end{array}$ & $\begin{array}{c}\text { On } \\
\text { dry } \\
\text { basis }\end{array}$ & $\begin{array}{c}\text { On } \\
\text { wet } \\
\text { basis }\end{array}$ & $\begin{array}{c}\text { On } \\
\text { dry } \\
\text { basis }\end{array}$ & $\begin{array}{c}\text { On } \\
\text { wet } \\
\text { basis }\end{array}$ & $\begin{array}{c}\text { On } \\
\text { dry } \\
\text { basis }\end{array}$ & $\begin{array}{c}\text { On wet } \\
\text { basis }\end{array}$ & $\begin{array}{l}\text { On dry } \\
\text { basis }\end{array}$ \\
\hline Sugar cane trash & 8.69 & 2.10 & 2.30 & 5.29 & 5.79 & 1.07 & 1.17 & 82.85 & 90.73 \\
\hline Sugar cane bagasse & 8.85 & 2.35 & 2.58 & 4.63 & 5.08 & 0.69 & 0.76 & 83.98 & 91.59 \\
\hline Dry sugar beet pulp & 5.87 & 8.56 & 9.09 & 10.07 & 10.70 & 0.36 & 0.38 & 75.14 & 79.03 \\
\hline $\begin{array}{l}\text { Sugar cane } \\
\text { molasses }\end{array}$ & 10.09 & 5.71 & 6.35 & 2.73 & 3.04 & 0.00 & 0.00 & 81.47 & 90.61 \\
\hline Sugar beet molasses & 10.06 & 6.46 & 7.18 & 3.74 & 4.16 & 0.00 & 0.00 & 80.74 & 88.66 \\
\hline
\end{tabular}

* Results are presented as average value for triplicate determinations.

**Calculated by difference.

Table 2. Chemical characterization of carbohydrate components of sugar cane and sugar beet by-products (on wet basis)*.

\begin{tabular}{|c|c|c|c|c|c|c|c|c|}
\hline \multirow[t]{2}{*}{ Starting by-products } & \multicolumn{3}{|c|}{ Sugars $(\%)$} & \multicolumn{4}{|c|}{ Non available carbohydrates (\%) } & \multirow{2}{*}{$\begin{array}{c}\text { Total } \\
\text { carbohydrates }\end{array}$} \\
\hline & $\begin{array}{l}\text { R.S. } \\
* *\end{array}$ & $\begin{array}{c}\text { NRS. } \\
* * *\end{array}$ & $\begin{array}{l}\text { Total } \\
\text { Sugars }\end{array}$ & Cellulose & $\begin{array}{l}\text { Hemi- } \\
\text { cellulose }\end{array}$ & Lignin & $\begin{array}{l}\text { Total } \\
\text { fibers }\end{array}$ & \\
\hline Sugar cane trash & 2.41 & 1.62 & 4.03 & 30.31 & 19.35 & 7.13 & 56.79 & 82.85 \\
\hline Sugar cane bagasse & 1.28 & 3.15 & 4.62 & 31.51 & 17.93 & 14.90 & 6434 & 83.48 \\
\hline Dry sugar beet pulp & 1.32 & 3.68 & 5.00 & 30.83 & 18.88 & 1.81 & 51.52 & 75.14 \\
\hline Sugar cane molasses & 39.11 & 25.08 & 64.19 & -- & -- & -- & -- & 81.47 \\
\hline Sugar beet molasses & 37.99 & 25.86 & 63.85 & -- & -- & -- & -- & 80.74 \\
\hline
\end{tabular}

* Results are presented as average value for triplicate determinations.

** R.S. = reducing sugar, $* * *$ NRS. $=$ non reducing sugars. 


\section{Non-available carbohydrate components:}

Data in Table (3) indicated that cellulose was the most dominant component in the tested sugar byproducts, where it comprised 34.57, 33.19 and $32.75 \%$ in SCB, SCT and dry SBP on dry basis, respectively. On the other hand, SCT contained the high hemicelluloses content $(21.19 \%)$ which seemed not to differ than that found in dry beet pulp $(20.06 \%)$ and sugar cane bagasse (19.67\%).

Furthermore, lignin, which is known to be the lowest value in cell wall constituent component, constituted about 1.92 and $16.35 \%$ for dry SBP and SCB on dry basis, respectively. However, lignin content of SCT was found to be in-between those values. It is well known that the presence of lignin in the cell wall has an important function in supporting and hardness of plant cells beside its vital role in cane and sorghum stem erection (Ahmed et al., 2000). On the other hand, the reduction in lignin content of dry SBP is excepted since it is obtained from beet root and no stem is present.

Other carbohydrate residue, which was not determined practically but calculated by difference, fluctuated between $16.39 \%$ for SCB and $24.32 \%$ for $\mathrm{SCT}$, while the other two by-products (molasses and dry SBP) were in-between those limits. These results are in agreement with those recorded by Alian $\boldsymbol{e t}$ al. (1987).

In agreement to the obtained data for nonavailable carbohydrates in SCB, Gaonkar and Kulkarni (1969) found that alpha cellulose content in bagasse was $35 \%$. However, higher values were reported by Alian et al. (1987) who noticed that depithed bagasse and bagasse pith contained alpha cellulose $49.75 \%$ and $48.63 \%$; hemicelluloses 26.11 and $28.8 \%$; lignin 17.88 and $22.68 \%$, and wax 3.00 and $3.26 \%$, respectively. Both of Aiello et al. (1996) and Garcia-perez et al. (2002) indicated similar values for cellulose (33.3 and $35.8 \%$, respectively).

Rezende et al. (2011) reported also comparable values that untreated bagasse had $35 \%$ cellulose, $25 \%$ hemicelluloses and $22 \%$ lignin, on a dry weight basis. In agreement to the obtained data, Masarin et al. (2011) estimated the chemical composition of SCB samples, obtained from experimental sugar cane hybrids as ranked by their lignin content, and reported that the average values were for lignin $16.8 \pm 0.1 \%$ and hemicelluloses $27.3 \pm 0.3 \%$. GarciaPerez et al. (2002) and Sun et al. (2004) reported comparable values for lignin (18.1 and $6.15 \%$, respectively) in bagasse.

Table 3. Chemical characterization of carbohydrate components of sugar cane and sugar beet by-products (on dry basis)*.

\begin{tabular}{|c|c|c|c|c|c|c|c|c|}
\hline \multirow[t]{2}{*}{ Starting by-products } & \multicolumn{3}{|c|}{ Sugars $(\%)$} & \multicolumn{4}{|c|}{ Non available carbohydrates (\%) } & \multirow{2}{*}{$\begin{array}{c}\text { Total } \\
\text { carbohydrates }\end{array}$} \\
\hline & $\begin{array}{l}\text { R.S. } \\
* *\end{array}$ & $\begin{array}{c}\text { NRS. } \\
* * *\end{array}$ & $\begin{array}{l}\text { Total } \\
\text { Sugars }\end{array}$ & Cellulose & $\begin{array}{c}\text { Hemi- } \\
\text { cellulose }\end{array}$ & Lignin & $\begin{array}{l}\text { Total } \\
\text { fibers }\end{array}$ & \\
\hline Sugar cane trash & 2.64 & 1.69 & 4.41 & 33.19 & 21.19 & 7.81 & 62.19 & 90.73 \\
\hline Sugar cane bagasse & 1.40 & 3.48 & 5.07 & 34.57 & 19.67 & 16.35 & 70.59 & 91.59 \\
\hline Dry sugar beet pulp & 1.40 & 3.71 & 5.31 & 32.75 & 20.06 & 1.93 & 54.73 & 79.83 \\
\hline Sugar cane molasses & 43.50 & 25.51 & 71.39 & -- & -- & -- & -- & 90.61 \\
\hline Sugar beet molasses & 42.24 & 27.31 & 70.99 & -- & -- & -- & -- & 88.66 \\
\hline
\end{tabular}

* Results are presented as average value for triplicate determinations.

** R.S. = reducing sugar, $* * *$ NRS. $=$ non reducing sugars.

Table 4. Some minerals contents in sugar cane and sugar beet by products.

\begin{tabular}{|c|c|c|c|c|c|c|c|c|c|c|}
\hline \multirow{3}{*}{ Starting by-products } & \multicolumn{8}{|c|}{ Minerals (g /100 g) } & \multirow{2}{*}{\multicolumn{2}{|c|}{$\begin{array}{c}\mathrm{Fe} \\
(\mathrm{mg} / 100 \mathrm{~g})\end{array}$}} \\
\hline & \multicolumn{2}{|c|}{ Silica } & \multicolumn{2}{|c|}{$\mathrm{Na}$} & \multicolumn{2}{|c|}{$\mathrm{K}$} & \multicolumn{2}{|c|}{$\overline{\mathrm{Ca}}$} & & \\
\hline & $\begin{array}{c}\text { On } \\
\text { wet } \\
\text { basis }\end{array}$ & $\begin{array}{c}\text { On } \\
\text { dry } \\
\text { basis }\end{array}$ & $\begin{array}{c}\text { On } \\
\text { wet } \\
\text { basis }\end{array}$ & $\begin{array}{c}\text { On } \\
\text { dry } \\
\text { basis }\end{array}$ & $\begin{array}{c}\text { On } \\
\text { wet } \\
\text { basis }\end{array}$ & $\begin{array}{c}\text { On } \\
\text { dry } \\
\text { basis }\end{array}$ & $\begin{array}{c}\text { On } \\
\text { wet } \\
\text { basis }\end{array}$ & $\begin{array}{l}\text { On dry } \\
\text { basis }\end{array}$ & $\begin{array}{c}\text { On } \\
\text { wet } \\
\text { basis }\end{array}$ & $\begin{array}{l}\text { On dry } \\
\text { basis }\end{array}$ \\
\hline Sugar cane trash & 0.49 & 0.54 & 0.43 & 0.47 & 0.41 & 0.45 & 0.43 & 0.47 & 0.12 & 0.13 \\
\hline Sugar cane bagasse & 0.61 & 0.67 & 0.46 & 0.50 & 0.38 & 0.42 & 0.38 & 0,42 & 0.13 & 0.14 \\
\hline Dry sugar beet pulp & 0.65 & 0.69 & 0.38 & 0.40 & 0.51 & 0.54 & 1.18 & 1.25 & 0.35 & 0.37 \\
\hline $\begin{array}{l}\text { Sugar Cane } \\
\text { molasses }\end{array}$ & 0.00 & 0.00 & 0.28 & 0.31 & 2.64 & 2.94 & 0.84 & 0.93 & 0.64 & 0.71 \\
\hline Sugar beet molasses & 0.00 & 0.00 & 0.97 & 1.08 & 4.56 & 5.07 & 0.50 & 0.56 & 0.30 & 0.32 \\
\hline
\end{tabular}


In contrast, higher values than those found in the present study for SCB were reported by Irfan $\boldsymbol{e t}$ al. (2011) who indicated that cellulose $(40 \%)$ lignin (23\%)were the main component of the total crude fibers in bagasse. Similarly, Varhegyi and Antal (1998) found similar higher values (cellulose of $40 \%$ and lignin of $20 \%$ ). Moreover, cellulose content was found to be also higher by Xu et al. (2006) of 43.6 $\%$.

In agreement to the obtained data, Kirby et al. (2006) indicated that sugar beet pulp was found to be rich in cellulose $(22-30 \%)$, hemicelluloses $(22-30 \%)$ and pectin (24-32\%), but low in lignin content (13\%). Michel et al. (1988) revealed that dried and washed dry SBP with ethanol 95\% contained 26-32\% hemicelluloses, 22-24\% cellulose. In addition, Andrei et al. (2012) reported comparable values for dry SBP content in cellulose (22-30\%), hemicelluloses (24-32\%), and lignin (3-7\%). The obtained results for lignin content are in agreement, with those of Michel et al. (1988) who reported comparable values for lignin (1-2\%) in SBP and also with those of Ahmed et al. (2000) and Dewraj (2004).

Higher values than those found for dry SBP in the present study were signaled by Allam (1993) who mentioned that, SBP contained cellulose $36.42 \%$ hemicelluloses $33.22 \%$. In the same trend, Youssif (1996) showed that dried SBP and SCB contained 46.12 and $59.11 \%$ cellulose, respectively, as well as $2.55 \%$ and from 21 to $30 \%$ lignin, respectively. She concluded that SCB and SBP could be considered as cellulose rich sources.

It should be mentioned that, higher values than those found for sugar cane trash in the present study were signaled by Sangkharak et al. (2011) who studied the sugar cane leaf waste ( trash) and found that it comprised of cellulose $(48.9 \% \pm 7.6)$, holocelluloses $(55.7 \% \pm 1.0)$ and lignin $(44.3 \% \pm 0.6)$.

Mineral content of raw materials:

As illustrated in Table (4), silica showed high content, on wet and oven-dry basis, in both dry SBP $(0.65$ and $0.69 \%$, respectively) and SCB (0.61 and $0.67 \%$, respectively), while SCT had somewhat lower values $(0.49$ and $0.54 \%$, respectively).Molasses from both sugar crops byproducts were found free of silica.

Sodium had the highest content, on wet basis and oven-dry basis, in sugar beet molasses ( 0.97 and $1.08 \%$, respectively), but sugar cane molasses showed the lowest values $(0.28$ and $0.31 \%$, respectively). Comparable intermediate $\mathrm{Na}$ contents were found in sugar cane bagasse (0.46-0.50\%), sugar cane trash $(0.43-0.47 \%)$ and dry beet pulp (0.38-0.40\%), respectively.

Potassium had the highest value, on wet basis and oven dry basis, in sugar beet molasses (4.56and $5.07 \%$, respectively), but sugar cane molasses which showed lower value (2.64 and $2.94 \%$, respectively) than sugar beet molasses. In contrast, the other by- products showed much lower content, but nearly comparable K values, with dry SBP $(0.51$ and $0.54 \%$, respectively), SCT (0.41 and $0.45 \%$, respectively) and SCB (0.38 and $0.42 \%$, respectively).

Calcium exhibited the highest content, on as is basis and oven dry basis, with dry SBP (1.18 and $1.25 \%$, respectively). In contrast, lower values than that found in dry SBP were showed with sugar cane molasses $(0.84$ and $0.93 \%$, respectively), sugar beet molasses ( 0.50 and $0.56 \%$, respectively), SCT $(0.43$ and $0.47 \%)$ and SCB $(0.38$ and $0.42 \%$, respectively).

Iron showed the highest content with molasses, on as is basis and oven dry basis, but sugar cane molasses had higher value (0.64 and $0.71 \%$, respectively) than sugar beet molasses (0.297 and $0.330 \%$, respectively). Dry SBP showed lower content ( 0.35 and $0.37 \%$, respectively) than sugar cane molasses, but comparable content to that for sugar beet molasses. The lowest values for Fe were found in SCB (0.13 and $0.14 \%$, respectively) and SCT ( 0.12 and $0.13 \%$, respectively).

In general, both sugar cane molasses and dry beet pulp were characterized by having higher content in silica. Dry SBP was characterized by having higher content in calcium. Sugar beet molasses contained the highest content in $\mathrm{k}$ and $\mathrm{Na}$, while sugar cane molasses contained highest content in iron. The reason for such observation could be that molasses is a black strap which came from juice concentration process by heating treatments which would results in increasing minerals ratio in molasses. Molasses did not contain any amount of silica, an observation which could explain their safe use as human food.

In accordance to results in the present study, molasses were reported to be rich in mineral and also vitamins (Singh et al., 2013). However, Abdel-Aziz et al. (2012) found higher values (in $\mathrm{g} / 100 \mathrm{~g}$ ) for potassium (0.201) and calcium (0.0115) and for iron (0.780), but comparable value for sodium (0.986).

Comparing results for dry SBP obtained in the present study with literature revealed somewhat compatibility. Majewsk and Krupinski (1979) reported comparable values for $\mathrm{Ca}(0.1079 \mathrm{~g} / 100 \mathrm{~g})$ and $\mathrm{Fe}(0.070-0.180 \mathrm{mg} / 100 \mathrm{~g})$ (on dry matter basis). Similarly, Saif (1991) found comparable results for potassium $(1.4 \%)$, but higher sodium (1\%). In agreement to the obtained results, Arosemena et al. (1995) found that SBP contained calcium of $1.14 \%$. In the same trend, Osman (1997) noticed that potassium content in sugar beet roots was $1.8 \%$. Moreover, Fadel (2000) reported comparable values for beet pulp, with regard to sodium $(0.46 \%)$ and potassium $(0.46 \%)$, but lower values calcium $(0.47 \%)$. In addition, Hagstrom (2008) reported that beet pulp was relatively high in calcium and low phosphorus content.

In agreement to the found data for bagasse, Moda et al. (2005) reported comparable values in sugarcane bagasse for sodium $(0.50 \mathrm{~g} / 100 \mathrm{~g})$, but 
higher for calcium $0.654(\mathrm{~g} / 100 \mathrm{~g})$ and iron $(0.096$ $\mathrm{mg} / 100 \mathrm{~g}$ ), in dry matter basis. In the same trend, Dias et al. (2007) indicated higher value for calcium $(0.9 \%)$ in cane bagasse. However, Dewraj (2004) reported lower value for potassium $(0.2163 \mathrm{~g} / 100 \mathrm{~g})$ than that found in the present study.

\section{References}

A.O.A.C. (1990). Official Methods of Analysis. Gaithersburg, 15th ed. MD, USA, Association of Official Analytical Chemists, Arlington, VA.

A.O.A.C. (2005). Official methods of analysis. Association of Official Analytical Chemists, $16^{\text {th }}$ Ed., A.O.A.C. International, Washington, D.C., USA.

Abdel-Aziz, S.M.; Hamed H.A.; Mouafi, F.E. and Gad, A.S. (2012). Acidic pH-Shock Induces the Production of an Exopolysaccharide by the Fungus Mucorrouxii: Utilization of BeetMolasses New York Sci. J., 5(2).

Abia, A.A.; Horsfall, M. and Didi, O. (2003). The use of chemically modified and unmodified cassava waste for the removal of $\mathrm{Cd}, \mathrm{Cu}$ and $\mathrm{Zn}$ ions from aqueous solution. Bioresource Technology, 90(3): 345-345.

Aiello, C.; Ferrer, A. and Leadsmen, A. (1996). Effect of alkaline treatments at various temperatures on cellulase and biomass production using submerged sugar cane bagasse fermentation with Trichoderma reesei QM 9414. Bioresource Technol., 57(1): 13-18.

Alian, A.M.; El-Masry, G.H.; El-Magoli, S.B. and Mohamed, M.F. (1987). Production of single cell protein from selected agro industrial solid wastes. Egypt. J. Food Sci. 19-30.

Allam, S.M. (1993). Biochemical studies on farm by-products. M.Sc. Thesis, Fac. Agric., Cairo Univ., Egypt.

Andrei, I.; Simion, P.E.; Dobrovici, R.; VavierTeodorescu, L. and Ciobanu, D. (2012). Mathematical modeling of the process of sugar beet pulp valorization by acid hydrolysis. Rov. Roum. Chim., 57(11): 915-920.

Anwar, S.I. (2010). Determination of moisture content of bagasse of Jaggery unit using microwave oven. J. Eng. Sci. and Technol., 5(4): 472-478.

Arosemena, A.; DePeters, E.J. and Fadel, J.G. (1995). Extent of variability in nutrient composition within selected by-product feedstuffs. Anim. Feed Sci. Technol. 54: 103120.

Beshai, M.G. (2001). Chemical composition and nutritive values of various cane by- products as affected by variety and drying methods. Egypt. J. Appl. Sci., 16(1): 83-98.

Blanco, C.J.; Bonelli, P.R.; Cerella, E.G. and Cukierman, A.L. (2000). Phosphoric Acid Activation of Agricultural Residues and Bagasse from Sugar Cane: Influence of the Experimental Conditions on Adsorption Characteristics of Activated Carbons. Industrial and Engineering Chemistry Research 39: 4166-4172.

Curtin, L.V. (1983). Molasses-general consideration: In: Molasses in animal nutrition. National Feed Ingredients Association, West Des Moines, Iowa.

Dewraj, T. (2004). Sugar cane bagasse, Mushroom Growers' Handbook, Chapter 5.

Dias, R.S.; Kebreab, E.; Vitti, D.M.S.S.; Roque, A.P.; Bueno, I.C.S. and France, J. (2007). A revised model for studying phosphorus and calcium kinetics in growing sheep doi: 10.2527/jas. -082. J ANIM SCI 2006, 84:27872794.

Dubois, M.; Gilles, K.; Hamilton, J.; Rebers, P. and Smith, F. (1956). Colorimetric method for determination of sugars and related substances. Analytical Chem., 28(3): 350-356.

Dumbrepatil, A.; Adsul, M.; Chaudhari, S.; Khire, J. and Gokhale, D. (2008). Effect of various pretreatment conditions on enzymatic saccharification. Songklanakarin J. Sci. Technol., 33(4): 397-404.

Fadel, M., 2000. Production physiology of cellulase and glucosidase enzyme of Aspergillus niger grown under solid state fermentation conditions. Biological Sci., 1(5): 401-411.

Gaonkar, S.M. and Kulkarni, P.R. (1989). Technical not: Utilization of sugar cane residues in foods. Inter. J. Food Sci. Technol., 24: 669.

Georging, H.K. and Van Soest, P.J. (1975). Agricultural Hand Book, 379, U.S. Dept. of Agric.

Hagstrom, J.D. (2008). Beet Pulp as a Fiber Source for Horses. University of Illinois/U.S. Department of Agriculture/Local Extension Councils Cooperating/University of Illinois Extension.

Irfan, M.; Gulsher, M.; Abbas, S.; Syed, Q.; Nadeem, M. and Baig, Sh. (2011). Effect of various pretreatment conditions on enzymatic saccharification. Songklanakarin J. Sci. Technol., 33(4): 397-404.

Kirby, A.R.; Macdogall, A.J. and Morris, V.J. (2006). Sugar beet pectien protein complexes. Food Biophysics., 1: 51-56.

Kühnel, S.; Schols, H. A. and Gruppen, H. (2011). Aiming for the complete utilization of sugar-beet pulp: Examination of the effects of mild acid and hydrothermal pretreatment followed by enzymatic digestion. Biotechnology for Biofuels, 4: 14 .

http://www.biotechnologyforbiofuels.com/content /4/1/14.

Legrouri, K.; Khouya, E.; Ezzine, M.; Hannache, H.; Denoyel, R.; Pallier, R. and Naslain R. (2005). Production of activated carbon from a 
new precursor olasses by activation with sulphuric acid. J. Hazard. Mater. B 118: 259-263.

Mariam, I.; Manzoor, K.; Ali, S. and Haq, I. (2009). Enhanced production of ethanol from free and immobilized saccharomyces cerevisiae under stationary culture. Pak. J.Bot., 41(2): 821-833.

Masarin, F.; Gurpilhares, D.B.; Baffa, D.C.F.; Barbosa, M.H.P.; Carvalho, W.; Ferraz, A. and Milagres, A.M.F. (2011). Chemical composition and enzymatic digestibility of sugarcane clones selected for varied lignin content. Biotechnology for Biofuels, 4: 55.

Meade, G.P. and Chem, J.C.P. (1977). Cane sugar handbook, $10^{\text {th }}$ Ed. Wiley, N.Y.

Michel, F.; Thibault, J.F.; Barry, J.L. and Baynast, R. (1988). Preparation and characterization of dietary fiber from sugar beet pulp. J. Sci. Food and Agric., 42(1): 77-85.

Mutah, M.; Akira, K.; Zaiton Abdul, M.; Jafariah, J.; Razman, S.M. and Eman, I.N. (2013). Production of sugar cane bagasse based activated carbon for $\mathrm{Cd}^{2+}$ removal using factorial design. Inter. J. Innovative Technol. and Exploring Eng., 2(4).

Osman, A.M.H. (1997). Effect of some micronutrients on yield and quality of sugar some micronutrients on yield and quality of sugar beet. Physico-chemical characterization of proteinassociated polysaccharides. extracted from sugar beet pulp. Carbohydrate Polymers 92 2257-2266.

Prabhakar, N.; Raju, D.V.L.N. and Vidya, S.R. (2010). Cane trash as fuel. Proc. Int. Soc. Sugar Cane Technol., 27.

Qureshi, Kh.; Inamullah, B.; Rafique, K. and Abdul Khalique, A. (2008). Physical and chemical analysis of activated carbon prepared from sugarcane bagasse and use for sugar decolorization. Inter. J. Chem. and Biological Eng., 1: 3 .

Rezende, C.; Marisa, A.E.; Maziero P.; Ribeiro, E.de A.; Garcia, W. and Polikarpov, I. (2011). Chemical and morphological characterization of sugarcane bagasse submitted to a delignification process for enhanced enzymatic digestibility. Biotechnology for Biofuels, 4: 54.

Saif, L.M.A. (1991). Yield and quality of sugar beet as effected by nitrogen sources and rate of some micro elements in Kafer El-Sheikh. Ph.D. Thesis, Fac. Agric., Ain Shams Univ., Egypt.
Samipa, D. and Chaudhuri, S.N. (2012). potentiality of sugarcane bagasse as an adsorbent for the removal of pesticides from drinking water. NeBIO 3(2): 107-111.

Sangkharak, K.; Rokeyoh, S. and Chompoonuch, W. (2011). Conversion of leaf waste to sugar and ethanol by shf and ssf fermentation using cellulose from Cellulomonas sp. Inter. J. Advanced Biotechnol. and Res., 2(3): 345-349.

Singh, J.; Solomon, S. and Kumar, D. (2013). Manufacturing Jaggery, a Product of Sugarcane, As Health Food. Agrotechnol., S11 ISSN:21689881 AGT, an open access journal Special Issue $11 \mathrm{http} / / / d x . d o i . o r g / 10.4172 / 2168-9881 . S 11-007$.

Snedecor, G.W. and Cochran, W.G. (1980). "Statistical methods" $17^{\text {th }}$ Ed. Iowa State Univ. Press Ames., Iowa, USA.

Sun, J.X.; Sun, X.F.; Zhao, H. and Sun, R.C. (2004). Isolation and characterization of cellulose from sugarcane bagasse. Polymer Degrdation and Stablity. 84: 31-339.

Torres-Pérez J.; Gérente C. and Andrès Y. (2012). Sustainable activated carbons from agricultural residues dedicated to antibiotic removal by adsorption.Chinese Journal of Chemical Engineering, 20(3): 524-529.

Varhegyi, G. and Antal, M.J.Jr. (1988). Simultaneous thermogravimetric-mass spectrometric studies of the thermal decomposition of biopolymers. 2. Sugarcane bagasse in the presence and absence of cata1ysts. Energy and Fuels. 2: 273-277.

Xia, L. and Len, P. (1999). Cellulose production by solid-state fermentation on lignocellulosic waste from the xylose industry. Process Biochem.34: 909-912.

Xu, F.; Sun, J.X.; Liu, C.F. and Sun, R.C. (2006). Comparative study of alkali- and acidic organic solvent-soluble hemicellulosic polysaccharides from sugarcane bagasse. Carbohydrate Research. 341: 253-261.

Youssif, N.A. (1996). Utilization of some industrial and agricultural wastes of sugar crops. Ph.D. Thesis, Fac. Agric. Kafr El-Sheikh, Tanta Univ., Egypt.

Zhang, Y.; Cui, H.; Ozao, R.; Cao, Y.; Chen, B.I.T.; Wang, C.W. and Pan, W.P. (2007). Characterization of Activated Carbon Prepared from Chicken Waste and Coal. Energy and Fuels, 21(6): 3736-3739. 


\section{تقييم الكريون المنشط المنتج من مخلفات المحاصيل السكرية. أولا: التركيب الكيميائى للمواد الخام الأوليه.}

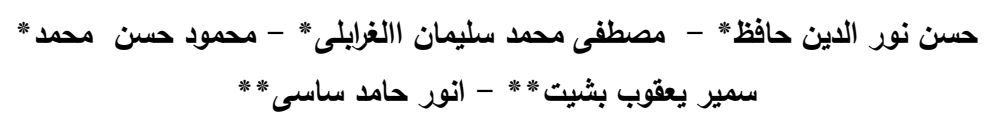

* قسم علوم الأغذية - كلية الزراعة بمثتهر - جامعة بنها.

" * معهد بحوث المحاصيل السكرية - مركز البحوث الزراعية - الجيزة.

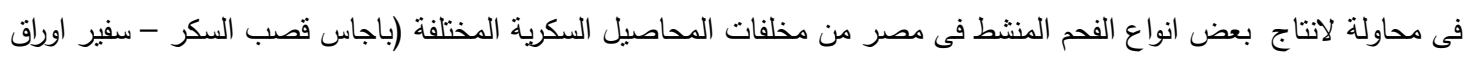

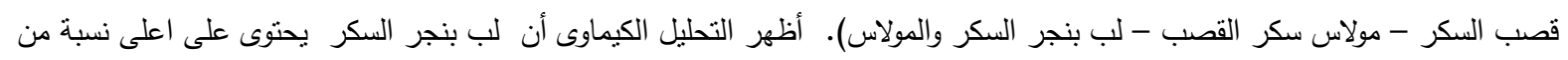

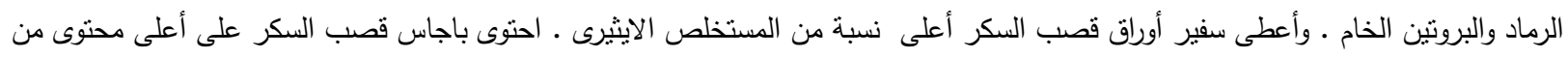

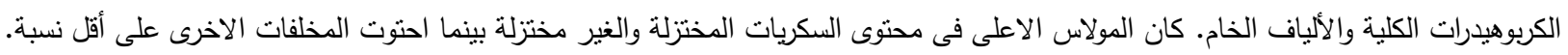

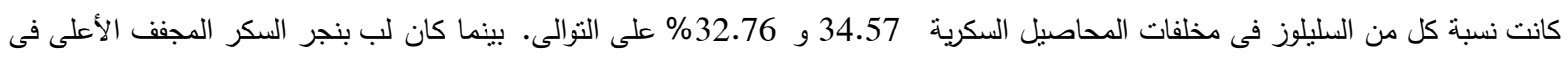

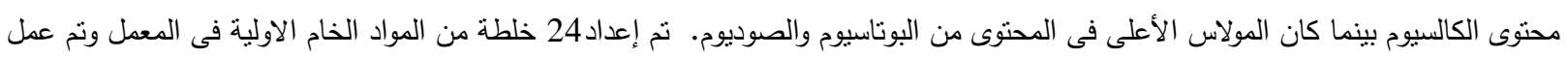

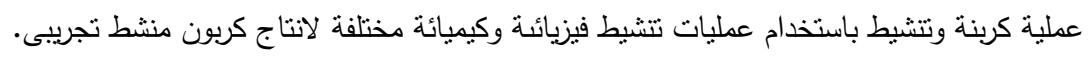

